\title{
Flipped Classroom's Validity, Applicability, and Reliability According to University and Private Sector Scholars' Perspectives in the Palestinian Context
}

\author{
Ahmed Awad Amin Raba' ${ }^{1}$ \\ ${ }^{1}$ Associate professor in TEFL, Faculty of Education and Teacher Training, An-Najah National University, Palestine \\ Correspondence: Ahmed Awad Amin Raba', Associate professor in TEFL, Faculty of Education and Teacher Training, \\ An-Najah National University, Palestine.
}

Received: July 22, 2020

doi:10.5430/wjel.v10n2p46
Accepted: September 21, $2020 \quad$ Online Published: September 24, 2020

URL: https://doi.org/10.5430/wjel.v10n2p46

\begin{abstract}
Teaching effectively produces the change for a better life, thus, the researcher conducted this study to figure out and analyze the potentiality of teaching via flipped classroom instructional method, according to senior lecturers of different Palestinian University perceptions along with the private sector scholars' perceptions. The researcher tried to detect the trend's reliability, validity, and applicability in the Palestinian context. The researcher conducted face-to-face interviews with 10 distinguished scholars in four Palestinian Universities who teach Methods of teaching EFL, applied linguistics and IT courses for master's degree graduates and others from the private sector local and international ones. The sample was predetermined from the private sector and the universities in Palestine. The researcher used qualitative research tools to analyze the collected data. The questions of the interview were designed as the consistency of its previous literature. The results of the analysis showed a significant weight for the flipped classroom model's validity, reliability and it also showed insignificance in the matter of applicability in the Palestinian Context. Further research will be of a great educational impact if similar research is conducted on a larger scale that will cover all the government and private schools.
\end{abstract}

Keywords: flipped classroom, private sectors' perspectives, university lecturers' perspectives, Palestinian educational system

\section{Introduction}

As technology witnessed a marginal development spread all over the world, this technology access has almost become reachable for all blended learning, active learning, gamification, and flipped classrooms turn to be the future of teaching-learning approaches over the traditional ones. Unfortunately, those still seem to be utilized individually by teachers in our Palestinian schools and even roughly in local universities Raba and Herzallah (2015), Heinerichs et al., (2016) and Dweikat and Raba' (2019).

\section{Statement of the Research Problem}

The outcomes of the Palestinian students graduating from both high schools to attend universities, and university graduate students, are under the expected level. This is mainly due to the use of traditional methods of teaching while modern approaches and trends are rarely used. Although there is an incredible speed technology emergence, the graduates fail to be recruited in the vacancies of the Job market Dweikat and Raba' (2018). The researcher is curious about the perspectives of the Palestinian local universities' lecturers and Private Sector Lecturers and organizers of advanced educational programs for pre and postgraduates.

\section{Purpose of the Study}

The teaching-learning process for ESL has been suffering from being taught in the traditional way disregarding, the massive technological progress that has taken place in our world. Besides, the occurrence of more than two dozen teaching approaches that give life to the teaching-learning process, unfortunately, is still neglected and unengaged in the curriculum design and the textbooks used in our formal education. The study attempted to explore more about the idea of the flipped classroom, its effects on the students, to what extent it is utilized by university lecturers, its merits and demerits, and the future of flipped classroom in the Palestinian context. 


\section{Questions of the Study}

The research aimed to collect and analyze the interviewees' perspectives about:

What is a flipped classroom?

How will the flip work?

What are their comments about "flipped classroom means eliminating face-to-face lectures"?

What distinguishes flipped classroom students from the other regular ones?

How are flipped classroom students evaluated and assessed?

How common is this trend in the Palestinian context?

\section{Significance of the Study}

This study aimed to compare the collected data from the interviewees' perspective to understand whether the flipped classroom model is valid, applicable, and reliable in the Palestinian platform.

\section{Literature Review}

In the area of teaching and learning, technology plays an integral part. Charaya, Bana, and Malhotra (2017) proposed that appropriate technological implementation has significantly changed the ways teachers teach and students learn. Moreover, teachers have felt a hidden pressure to integrate technology in their lessons which forces them to re-evaluate their teaching styles. Rather than avoiding the call, educators should incorporate technology into their teaching, applying its advantages towards achieving learning objectives. Technology has limitless potentials in education; therefore, teachers strive for various ways to incorporate technology into their classrooms to create better and sustainable learning for their students Long; Logan and Waugh (2016). A learning environment with technology integration can enrich learning environment with the use of technologies that can offer students better and long-life learning Hsieh; Wu and Marek (2017)). Because new technologies offer them unique opportunities, language teachers have particularly been integrating technology into their lessons more and more, Webb and Doman (2016). With the proper use of the different technological tools, teachers aim to present rich learning experiences to the students and to create a more engaging and motivating classroom atmosphere where the roles of teachers, textbooks, and students are flipped Raba' (2017). Among the technological mediums, video is an effective teaching tool when used properly. Al-Harbi \& Alshumaimeri (2016), and teachers all over the world have been using it to support their instruction. Video lectures, which are different from simply showing videos in the classroom, are not a new concept; however, the technology used to produce, edit, and distribute such videos has become far more accessible to teachers Whitley-Grassi \& Baizer, 2010). In this context, the flipped classroom can "improve learning experiences and capture the attention of Millennial students" (Roehl, Reddy, \& Shannon, 2013, p. 49). One method for incorporating technology like videos is the flipped or inverted classroom, which brings an innovative perspective to traditional lectures.

Li, W. (2017) has also stated that flipped classroom has a strong relationship with the subject of Decision making especially when integrated with the traditional method of teaching. Tseng and others (2016) indicated implementing the flipped classroom in four stages, watching videos, taking notes while watching the video, answering the preview questions, and having immediate feedback. Their study showed positive signs in note-taking and test scores.

Engin and Donanci, (2016) conducted a project of showing instructional videos that highlighted writing skills. This project indicated that video input is very important but has to be integrated with the instructor of the course to yield better understanding.

Aşıksoy, and Özdamlı, (2016) showed the obvious effect of the flipped classroom adapted to Keller's ARCS over achievement, motivation, and self-sufficiency of students applied in the physics course. Hence, there was an increase in motivation and self-sufficiency in the experimental group where students showed enthusiasm towards flipped classroom approach.

Basal (2015), pinpointed the effectiveness of flipped classrooms dominated by technology on the learning and motivation of students. He found out that the flipped classroom yielded both greater academic achievement and greater motivation compared with the traditional approach. He ended his research by sharing the requirements for implementing flipped classroom by saying that the teacher should be as a facilitator, and the student should be the main body of teaching, giving full play to the supporting role of internet positively, analysis and research, preparation before the class, classroom discussion and finally after class feedback and question answering.

The education system is the main social institution, through which all types of people adapt to changing Published by Sciedu Press 
socio-economic conditions, easing, simplifying the way they live to teach, learn, and communicate. This, in turn, can increase personal motivation which contributes to a significant improvement in the quality of education Kasyanov (2019). As learning is the driving force of the future and learning languages is the bridge between cultural exchanges, a flipped classroom is a device that ensures progress over the students' learning skills. As examples of flipped classrooms Zhang, et al, 2016) the teacher teaches the appropriate manner of articulation and place of articulation, then the teacher asks his students to repeat loudly the vowels and consonants, Errors will be pointed out and more practice will be needed. The flipped classroom came to rescue those individuals to improve their skills in pronunciation.

As Dong, (2016) indicated, English learning consists of "listening, reading, writing, and speaking the college English course setting in China's colleges concentrate mainly on the college intensive English, Extensive Reading, Grammar, Listening, and Oral English, and the teaching materials generally adopted are the college English series. Teachers are required to finish the English heavy tasks in a limited time". Dong continues to emphasize the importance of using the flipped classroom "It is certain that the innovative education model of the flipped classroom conforms to Chinese college student' learning conditions and characteristics, having relatively high advantages, integrity and innovation in terms of teaching idea, teaching goals, with classroom teaching and made interaction inside and outside the classroom as well as "online- offline. Moreover, many studies indicated and stressed on the importance of vocabulary as a base in language acquisition. Zhang 2, et al,2016) stated that Vocabulary is the foundation of any language and it holds an important rank in the linguistic system. They also indicated that due to the traditional way of teaching the English language the effectiveness of passing the required amount of vocabulary is low due to having extensive teacher-centered classes, then they concluded that the limitations of reaching high standards of vocabulary can be overcome by using flipped classroom model due to its flexibility, interaction, peer discussions, autonomous searching, and thinking.

The flipped classroom is a revolutionary model that can transfer teaching from being a dead unfruitful device to a lively one. It transmits the roles of being teacher-centered into student-centered. It also prepares the student to be a researcher rather than a receiver. In 2000, Lage Platt, and Treglia published a study titled "Inverting the Classroom: A Gateway to Creating an Inclusive Learning Environment." About the study, there is a huge use of technological communicative devices that are easy to access. This caused ease in being connected to those devices which caused more space of time and saying goodbye to worrying about the course coverage. " "Inverting the classroom means that events that have traditionally taken place inside the classroom now take place outside the classroom" (Lage, Platt, $\&$ Treglia, 2000, p. 32). The core difference in this trend is providing more space of time to each student outside the class to review the Multimedia material as much as he needs, and by this the model allows the student to write notes and internalize the ideas. On the other part, inside the class, the student interacts and discusses with his peers and teachers. This model creates a sense of responsibility within the learner towards his learned materials. The teacher whose role in this model as a facilitator prepares, online lectures links, interactive quizzes, worksheets that check the students' completion of homework, and the grasp of the targeted knowledge. Students also in this model engage and practice demonstrations, experiments, labs------etc, under the supervision of the instructor. (Lage, Platt, \& Treglia, 2000, p. 37) referred to a positive impact over the students' motivation who applied this model.

Finally, the literature review identifies several barriers to technology integration. These barriers include access to resources, time, technical support, teacher beliefs, teacher readiness, overall support, and leadership. According to some researchers, the most common external barrier, access to resources, is a huge impediment to technology implementation Marsumoto, T. 2016; Berge \& Mrozowski, 2001; Mumtaz, 2000, and Egbert, Herman, D., \& Lee, 2015)

\section{Methodology}

The researcher tended to use qualitative research to analyze the collected 10 transcribed interviews, coding them, and categorizing them, then comparing them to each other. To establish that, the researcher designed six questions to be asked to 10 University's MA Professors from various Palestinian Universities, 5 of them are professors of applied linguistics of English language and TEFL, one is a former vice president of Kansas University and international educational aid employer, three IT professors and one private-sector scholar working in educational affairs. The interviews were recorded then transcribed to be reviewed and coded. The interviewees' names were not mentioned in this study.

\section{Instrumentation}

The basic and only instrument used in this qualitative research was face-to-face interviews which were analyzed by comparing coded items and categories. 


\section{Selection of Sample}

The researcher predetermined a group of professors, who participated in previous conferences related to e-learning, those had a reputation in addressing the new teaching approaches in e-learning and blended learning, those represented multi-local universities, on the other hand, the researcher grasped the opportunity of attending the second international conference for learning and teaching in the digital world in An-Najah university (2017), to conduct interviews with the private sector and international participants in the conference. This attempt added a wider perspective to this research.

\section{Analysis and Findings}

The following are summaries for some of the interviews that coded items were derived from.

Summary 1 -Associate professor at Al-Istiqlal University in Jericho

The flipped classroom is a tremendous trend that requires prepared videos, tubes, movies, taped visual demonstrations, and recorded lectures.... etc. The students are asked to access these tubes at home, with the ability to rewind as many times as possible until the student gets the main ideas of the exposed material. The next day, the teacher has already prepared certain activities that require peers' pairs, and the group works cooperatively and collaboratively. The students discuss, interact, give feedback to each other. The teacher's role is monitoring and giving final feedback. In other words, the students are equipped with a foundational understanding of the material, which enables them to engage in the class discussion and activities without the need for the teacher to explain the basics of the materials. This allows more time-space for digging in-depth in the chosen materials and transmitting the learning process where the roles of the teacher and students were reversed. The interviewee also insisted that the step of changing the traditional system of learning into E-learning which includes flipping classes needs some national scale experts from both governmental and private sectors to design a new curriculum based on E-learning. On the other hand, he stated that until now he foresees no real intentions to do so.

Summary 2 -A specialist in English and linguistics and the former academic vice president of Kansas University for four years.

The teacher has to have consideration of class nature when choosing materials and design the flipped materials and their clear instruction. This approach has to be informed to the parents to be aware of which class sessions the teacher is planning to flip. The parents' role here, is to follow up with their sons and make sure that they review and get access to the online published materials and ensure their interaction in the classroom. According to assessment in the flipped classroom, it is not so far different from the perspective of the lecturers when compared to the traditional way. The lecturers of the flipped classroom have to prepare quizzes formative assessment tests, ask for more assignments, essays, and other things. However, the flipped classroom trend seeks to change the student's learning methods techniques, styles, and the environment. This means, turning the student to be a researcher, person of logic and critique, and an opened appetite knowledge seeker. Moreover, to transmit the passive instructional environment, which is both boring and frustrating into an interactive vital, and enthusiastic one. Both factors play a vital role in improving the students' results and ultimately motivate them widely to deal with all the forms of quizzes and assignments because they are more informative.

\section{Summary 3- Professor in (An-Najah University)}

Unlike the traditional approach where the gap between the teacher and the students is wide, the flipped classroom approach makes them closer to each other. Based on that, she stressed the idea that flipping the classroom means both online prepared materials in addition to, face-to-face lecturing. Otherwise, this approach will not succeed. "Our concern usually as tefl lecturers is to reinforce students to work more and interact with us more. We used many approaches with the students to encourage them to work on their own to show more engagement. However, we realized that we need to give them more space to work individually, in addition to face- to -face tutoring, to be more responsible about their learning, but I think we haven't reached the aimed destination yet."

To make the flipped classroom work, scholars have to focus on both mixture courses online and face-to-face lecturing to integrate the learning process. We as educators are aiming to make the students work on their own, but this doesn't mean that the role of the teacher is neglected, it has to be there. We have online courses but the students have to be always pushed and reminded to go through the online references. We are shortening the time of the lectures to the Master graduates to give them enough time to review online materials downloaded into their Moodle "Dr. Arafat described the notion by" The students' readiness is still not there, and we need to spread awareness of this method gradually. 


\section{Summary 4- Associate professor at Al-Quds Open University}

The traditional way of teaching turns the students to be passive learners, but in the flipped classroom students play a more interactive and collaborative role, especially that they turn to engage more in both discussions, and experimentations. By the repetition of the daily different tasks, while practicing the Model, this consequently forms what is called personalized learning. this means that the students dramatically change their style of learning because they watch the material, analyze it, write notes, then demonstrate their grasped skills and data in writing or and discussing verbally with their peers and teachers, perform interactive quizzes, give feedback to their colleagues, and ask deeper questions about the topic taught for the teacher. He also focused on the idea of providing the student with the exact time needed to understand the ideas of the material which is significant compared with the previous traditional way which showed incompetency to do so with students. He also emphasized the increased time of the class provided when flipped changes the role of the teacher to be a guide rather than being spoon feeder.

Summary 5- (Amra Information Technology)

He stated that the flipped classroom is the newest trend in improving the classroom experience. But unfortunately, in the Palestinian context, it is still invalid although there are certain strategies and conferences that the Palestinian Authority is taking into consideration these days. The matter of delaying the real practice of E-learning, which includes the flipped classroom, is purely Finance. The state is working on proposing for enough subsidies, and there are many European countries, that are ready to do that. He also added that this method needs certain policies to be taken by the state to improve the quality of learning.

Summary 6: Abu Deis University:

The interviewee discussed the qualities of the flipped classroom and also its cons. He stated that the notion of the flipped classroom represents an innovative transmission of the traditional way of teaching too much higher standard of practicing bloom's taxonomy in all its levels while the steering of learning is driven by the student. On the other hand, he has foreseen many challenges, that might lower the effect of it in the Palestinian educational platform. For example, he tackled the problem of internet access for all the students especially the ones living in remote areas, and suffering poverty. This will frustrate them rather than being a motivating trend. Besides, the control over reviewing materials by the students is going to be hard to monitor. Add to this, that the mentality of the traditional core lecturers and teachers which might resist the new approach, and might neglect it, for it needs extra time from them to prepare the online materials for students.

All the above don't mean that I don't ever flip my classes. On the contrary. But I believe that this can work better with senior students, not freshmen. The state has to put into consideration that active learning, blended learning and flipped classrooms won't be applied on a national scale until the Ministry of education sets a strategic plan and adopt certain policies that integrate all the needed items for a newly born foundation based on this modern trends and e-learning.

\section{Analysis and Discussion}

The transcribed interviews were analyzed under three main categories: Flipped classroom's validity, reliability, and applicability. Validity holds many codes under its umbrella such as students' responsibility towards online homework, and time consumption in the classroom. Face-to-face teaching unaccustomed traditional teachers with more work over instructors, and assessment. Reliability also has tackled many codes under it, such as student-centered, teacher as a facilitator, subject matters, peer discussion, collaboration, and cooperation. Applicability also renders internet access, financial challenges, the state's policy, and laws. As table 2 indicates, the coded items had numbers from 1-20 and each interview had the number of codes that had been addressed in the interview.

\section{Results and Discussion}

According to table one, all three categories were addressed by the interviewees implicitly, but the analysis of the figures shows them more clearly.

Code 1- responsibility toward online homework: was addressed by participant's \# 2,3 and 7. All the views met on one path, which is the students' responsibility toward the online courses still need more effort and follow up.

Code 2- "Time consumption at the classroom" the three above participants commented on-time utility in the classroom discussion and feedback. Since the students prepare the basics of the materials online, this leaves a considerable margin of time to peer and group work, discussion, and performing certain activities in the classroom.

Code 3- Face-to-face teaching was addressed by participants 1,2,3,9. All participants stressed the importance of face to face lecturing in addition to the online materials to integrate the learning process. 
Code 4-Unaccustomed traditional teachers: Participants 7,9 addressed the code by saying that there are a huge number of teachers who are not accustomed to flip their classroom and this would be a challenge for practicing the model.

Code 5- More work over instructors: Only number eight presented it as a challenge especially for those using the pure traditional methods and have no access to technological means.

Code 6- Assessment change, participants 2,7,8,9 expressed the importance of being aware that flipping the classroom doesn't mean changing the whole assessment system on the contrary it may be the same as the user with the traditional method. Formative and summative assessments are accompanying the flipping process. Flipping classroom means changing the learning style and the nature of the learning environment that facilitates the students' ability to perform well in both formative and summative assessments.

Code 7- Online materials: almost all the participants agreed that the lecturer has to be resourceful and trained to do so otherwise, the lecturer won't be able to guide the given courses successfully. Consequently, the result of the above code shows a clear and significant result for the validity of the flipped classroom.

Code 8: Student-centered, participants: \# 1, 4,5,6,8 all focused on the result that transmits the teaching process from being teacher-centered to student-centered.

Code 9- Teacher as a facilitator, Participants \# 6,7,9,10 focused more than others about the role of the teacher in the flipped classroom and described him as a facilitator who prepares materials and monitors students' discussion and activities' performance and finally gives feedback to the outcomes of his students in the class.

Code 10- Subject matters: Participants \# 2,8,9 stressed that personalized learning attach learners more to the lively subject matters that are more likely related to real-life situations.

Code 11- Peer discussion: Mostly all participants focused on the peer discussion whether it is paired or grouped and their benefit when flipping the classroom.

Code 12- Collaboration and cooperation: 6 participants commented on collaborations and cooperation as an important character of the flipped classroom and its importance in exchanging information and giving feedback to each other.

Code 13- Personalized learning and self-motivation: Participants \# 1,3,4,6 explained this concept and said that the flipped classroom tends to transform the passive student into a motivated self-dependent and ambitious learner.

Code 14- Internet access: participant\# 6 commented that one of the challenges that face the application of this model is the non-accessibility of the internet for all the students particularly the ones who live in remote areas, and the poor ones with no internet access at their homes.

Code 15- Financial challenges: Participant \# 2,4,6,8 commented that the thing that delays implementing this approach on the national scale is finance problem but they added that the Palestinian Authority should present a proposal to the international donors.

Code 16- State's policy and law: Participant \# 1,2,6 commented that the Palestinian State has already had a law of the welfare of the educational process but it is a matter of politics and finance that had already delayed having E-learning in practice on the national scale.

Code17-States' willingness: Participant \# 1,2, 6 commented that there is a willingness to make a change but this will have to be related to certain strategies, and actions. Participant one was pessimistic and said," he has foreseen no practical sign to do so". Number two and six participants were less pessimistic and referred to the need for spreading awareness led by the ministry of education, but this is still weak and represented only through university conferences.

Code18-How to solve the problem? participant \# 1,2,6 commented that the problem of applying e-learning in the Palestinian Platform will be solved only if the state takes certain measures and collaborate integrated energies from both the private and public sectors.

Code19- Lecturers' willingness participant \# 1,2,6,8, 9,10 commented that the awareness of this foundational change is still low and needs to be enforced by the law authority, well-planned strategies, and universities' regulations.

Code 20- E-learning awareness over lecturers and students' participant \# 3 commented that Some university lecturers are using the model partially, but the students need to be monitored and pushed to do their online homework regularly. 


\section{Conclusion}

The researcher coded findings expressed neutral significance when addressing the perspectives about the validity but on the other hand, showed a positive sign when addressing the perspectives regarding reliability of Flipped classroom. This appeared clearly in the codes $2-16$, personalized learning got great emphases from the interviewees because of using the flipped classroom, the changed vision of the learning environment. On the other hand, there were some significant negative perspectives towards the applicability willingness from the Palestinian Authority side which is challenged by many factors such as, financial problems, predetermined laws, and setting some reliable strategies by both private sector and public ones, and spreading awareness amongst both teachers and students about this distinguished approach.

\section{I4. Recommendations}

This qualitative project addressed the trend of the flipped classroom in a small sample which is ten scholars, therefore, the study closes with the following recommendations: to have a broader study and target both Lecturers and students in all the universities and private sector advanced programs to be able to use the outcomes in accelerating the transmission of the E-learning into a reality. More studies to be conducted in public schools as well. In this regard, teachers will gain adequate opportunities to practice the flipped classroom model in their classes.

As long as the university is the head of the arrow in the learning process and plays a foundational role in it, the university should use the online courses for both under and postgraduates more intensively and count credits for that.

Finally, organizing school and university workshops should help students and teachers exchange experience and discuss recent educational trends such as the promotion of self-learning and life-long education skills via flipped classrooms.

Table 1. Delivered code to each interviewee

\begin{tabular}{|l|l|l|l|l|l|l|l|l|l|}
\hline $\begin{array}{l}\text { Summary } \\
\text { Ten }\end{array}$ & $\begin{array}{l}\text { Summary } \\
\text { nine }\end{array}$ & $\begin{array}{l}\text { Summary } \\
\text { eight }\end{array}$ & $\begin{array}{l}\text { Summary } \\
\text { Seven }\end{array}$ & $\begin{array}{l}\text { Summary } \\
\text { six }\end{array}$ & $\begin{array}{l}\text { Summary } \\
\text { Five }\end{array}$ & $\begin{array}{l}\text { Summary } \\
\text { four }\end{array}$ & $\begin{array}{l}\text { Summary } \\
\text { Three }\end{array}$ & $\begin{array}{l}\text { Summary } \\
\text { two }\end{array}$ & Summary one \\
\hline $\begin{array}{l}\text { Code } \\
2\end{array}$ & $\begin{array}{l}\text { Code } \\
6\end{array}$ & $\begin{array}{l}\text { Code } \\
6\end{array}$ & $\begin{array}{l}\text { Code } \\
12\end{array}$ & $\begin{array}{l}\text { Code } \\
8\end{array}$ & $\begin{array}{l}\text { Code } \\
14\end{array}$ & $\begin{array}{l}\text { Code } \\
12\end{array}$ & $\begin{array}{l}\text { Code } \\
3\end{array}$ & $\begin{array}{l}\text { Code } \\
6\end{array}$ & $\begin{array}{l}\text { Code } \\
11\end{array}$ \\
\hline 8 & 3 & 8 & 4 & 9 & 15 & 11 & 12 & 10 & 12 \\
\hline 11 & 10 & 10 & 1 & 13 & 16 & 13 & 13 & 2 & 3 \\
\hline 12 & 18 & 14 & 6 & 15 & 17 & 2 & 19 & 7 & 7 \\
\hline 9 & 9 & 17 & 7 & 18 & 18 & 8 & 20 & 16 & 8 \\
\hline 15 & 7 & 18 & 8 & 17 & 20 & 9 & 17 & 17 & 17 \\
\hline 16 & 4 & 5 & 9 & 20 & 13 & 20 & 8 & 12 & 13 \\
\hline
\end{tabular}

Table 2. Categories and codes

\begin{tabular}{|l|l|l|}
\hline $\begin{array}{l}\text { Category } \\
\text { Applicability in the Palestinian Context }\end{array}$ & $\begin{array}{l}\text { Category two } \\
\text { Reliability }\end{array}$ & $\begin{array}{l}\text { Category one } \\
\text { Validity }\end{array}$ \\
\hline \multicolumn{1}{|c|}{ Code and number } & Code and number & \multicolumn{1}{c|}{ Code and number } \\
\hline 14- internet access & 9-teacher as a facilitator & $\begin{array}{l}\text { 1-Responsibility towards } \\
\text { online homework }\end{array}$ \\
\hline 15- financial challenges & $\begin{array}{l}\text { 2-The space time of the } \\
\text { classroom }\end{array}$ \\
\hline 16- state's policy and law & 11-peer discussion & $\begin{array}{l}\text { 3-Face-to-face teaching } \\
\text { teachers }\end{array}$ \\
\hline 17- states' willingness & $\begin{array}{l}\text { 12-collaboration } \\
\text { cooperation }\end{array}$ & $\begin{array}{l}\text { 5- more work over instructors } \\
\text { self-motivation }\end{array}$ \\
\hline 18- how to solve the problem & & 6- assessment change \\
\hline $\begin{array}{l}\text { 19- lecturers' willingness - } \\
\text { and students }\end{array}$ & and & online materials \\
\hline
\end{tabular}

\section{About the author}

Ahmed Awad Amin Raba' is an associate professor in the Faculty of Education and Teacher Training Department of Methods of Teaching English, An-Najah National University, Palestine. He works in the areas of TEFL and TESL. 
His recent research interests are TEFL, TESOL, games in teaching, motivation, curriculum analysis, and evaluation. ORCiD ID: https://orcid.org/0000-0002-7688-5613

\section{Acknowledgment}

The researchers would like to thank scholars, university professors, private sector participants who took part in this study during the second semester of the academic year 2018-2019. Thanks are also extended to the Methodology Department and the English Language and Literature Department at An-Najah National University. Special thanks to Ibrahim Ali Ata Baidoun, a teacher in Ibn Rushd Comprehensive School Boys- Jerusalem for his great support in helping the researcher in data collecting.

\section{References}

Al-Harbi1, S. S., \& Alshumaimeri, Y. A. (2016). The Flipped Classroom Impact in Grammar Class on EFL Saudi Secondary School Students' Performances and Attitudes. English Language Teaching, 9(10), 60-80. https://doi.org/10.5539/elt.v9n10p60

Aşıksoy, G., \& Özdamlı, F. (2016). Flipped classroom adapted to the ARCS model of motivation and applied to a physics course. Eurasia Journal of Mathematics, Science \& Technology Education, 12(6), 1589-1603. https://doi.org/10.12973/eurasia.2016.1251a

Basal, A. (2015). The implementation of a flipped classroom in foreign language teaching. Turkish Online Journal of Distance Education, 16(4), 28-37. https://doi.org/10.17718/tojde.72185

Berge, Z., \& Mrozowski, S. (2001). Review of research in distance education, 1990 to 1999. American Journal of Distance Education, 15(3), 5-19. https://doi.org/10.1080/08923640109527090

Charaya, A., Bana, V., \& Malhotra, R. (2017). Impact of ICT on Creativity and Achievement Ability of Perspective Teachers and Students of Technical Education. International Journal on Arts, Management and Humanities, $6(2), 15-22$.

Dong, X. N. (2016). Application of the flipped classroom. In College English Teaching. Creative education, 7 , 1335-1339. https://doi.org/10.4236/ce.2016.79138

Dweikat, K., \& Raba' A. (2019). English as a Foreign Language (EFL) Teachers' Perceptions of the Flipped Classroom Model in Palestine. IUG Journal of Educational and Psychological Sciences Peer-reviewed Journal of Islamic University-Gaza, 27(03), 29-47.

Dweikat, K., \& Raba, A. (2018). Lessons learned from using the Flipped Learning Model for Teaching Psycholinguistics at An-Najah National University. International Journal of Research in Management \& Social Science, 6(1).

Egbert, J., Herman, D., \& Lee, H. (2015). Flipped Instruction in English Language Teacher Education: A Design-Based Study in a Complex, Open-Ended Learning Environment. Tesl-Ej, 19(2), 2.

Engin, M., \& Donanci, S. (2016). Instructional videos as part of a 'flipped' approach in academic writing. Learning and Teaching in Higher Education: Gulf Perspectives, 13(1). https://doi.org/10.18538/lthe.v13.n1.231

Heinrichs, S., Pazzaglia, G., \& Gilboy, M. B. (2016). Using Flipped Classroom Components in Blended Courses to Maximize Student Learning. Athletic Training Education Journal, 11(1), 54-57. https://doi.org/10.4085/110154

Hsieh, J. S., Wu, V., \& Marek, M. W. (2017). Using the Flipped Classroom to Enhance EFL Learning. Computer Assisted Language Learning, 30(1-2), 1-21. https://doi.org/10.1080/09588221.2015.1111910

Kalyanova, L. M. (2019). The Project Method in Teaching Special Disciplines to Students of Technical Universities. International Journal of Emerging Technologies, 10(3), 23-26.

Li, W. (2017). The Explorer of Decision-Making in Class. In Proceedings of the Fourth International Forum on Decision Sciences (pp. 317-323). Springer, Singapore. https://doi.org/10.1007/978-981-10-2920-2_28

Long, T., Logan, J., \& Waugh, M. (2016). Students' Perceptions of the Value of Using Videos as a Pre-Class Learning Experience in the Flipped Classroom. TechTrends: Linking Research and Practice to Improve Learning, 60(3), 245-252. https://doi.org/10.1007/s11528-016-0045-4

Marsumoto, T. (2016). The Flipped classroom Experience of Gamified Creative Education, 7, 1475-1479. https://doi.org/10.4236/ce.2016.71015

Maureen J. L., Glenn, J. P., \& Michael, T. (2000). Inverting the Classroom: A Gateway to Creating an Inclusive 
Learning Environment. The Journal of Economic Education, 31(1), 30-43. https://doi.org/10.1080/00220480009596759

Mumtaz, S. (2000). Factors affecting teachers' use of information and communications technology: a review of the literature. Journal of Information Technology for Teacher Education, 9(3), 319-342. https://doi.org/10.1080/14759390000200096

Raba, A. A. A. (2017). The Influence of Think-Pair-Share (TPS) on Improving Students' Oral Communication Skills in EFL Classrooms. Creative Education, 8, 12-23. https://doi.org/10.4236/ce.2017.81002

Raba, A., \& Herzallah, H. (2015). Effective teaching from An-Najah National University M.A. Students' perspectives. Journal of Languages and Culture, 6(6), 52-60. https://doi.org/10.5897/JLC2015.0325

Roehl, A., Reddy, S. L., \& Shannon, G. J. (2013). The flipped classroom: An opportunity to engage millennial students through active learning strategies. Journal of Family and Consumer Sciences, 105(2), 44-49. https://doi.org/10.14307/JFCS105.2.12

Tseng, M. F., Broadstock, M., \& Chen, H. (2016). An Investigation of the Design of a Four-stage Flipped Classroom in Mandarin Chinese.

Webb, M., \& Doman, E. (2016). Does the Flipped Classroom Lead to Increased Gains on Learning Outcomes in ESL/EFL Contexts? The CATESOL Journal, 28(1), 39-67.

Whitley-Grassi, N., \& Baizer, J. S. (2010). Video lecture capture in physiology courses: Student attendance, video viewing, and correlations to course performance. International Journal of Instructional Technology and Distance Learning, 7(10), 31-38.

Zhang, H. W., Du, X. M., Yuan, X. F., \& Zhang, L. M. (2016). The Effectiveness of the Flipped Classroom Mode on the English Pronunciation Course. Creative Education, 7, 1340-1346. https://doi.org/10.4236/ce.2016.79139

Zhang, H. W., Li, J., Jiao, L. P., Ma, W. L., \& Guan, C. (2016). The Adjustment and Effects of Vocabulary Teaching Strategies in Flipped Classroom. Creative Education, 7, 1966-1973. https://doi.org/10.4236/ce.2016.714199

\section{Copyrights}

Copyright for this article is retained by the author(s), with first publication rights granted to the journal.

This is an open-access article distributed under the terms and conditions of the Creative Commons Attribution license (http://creativecommons.org/licenses/by/4.0/). 